\title{
KULTUROWA TOŻSAMOŚĆ SZKOŁY SALEZJAŃSKIEJ PODSTAWĄ WYCHOWANIA KU ŻYCIU WARTOŚCIOWEMU
}

\begin{abstract}
Streszczenie: Każda organizacja wykształca swoją własną kulturę. Kultura organizacji w dużym stopniu definiuje zachowania jej członków, stanowi klucz do ich interpretacji. Poznanie kultury umożliwia lepszy wgląd w rozumienie ludzkich zachowań. Każda szkoła jest elementem szerszej kultury społeczeństwa i narodu, wprowadza w kulturę i ją buduje, pomaga w niej konstruktywnie uczestniczyć i twórczo się rozwijać. Jako społeczność ma swoją wewnętrzną kulturę - swoją historię, tradycję, obrzędowość, symbolikę, swoje wartości, wzory, normy zarówno formalnie deklarowane i zapisane, jak i nieformalnie funkcjonujące, typowe zachowania członków społeczności szkolnej, język i sposoby porozumiewania się, sposoby rozwiązywania problemów, styl działania i atmosferę. Kultura ta oddziałuje na samo środowisko danej szkoły, ale i szerzej, na zewnątrz, przez naturalne interakcje społeczne i programowe działania na rzecz innych. Zatem inaczej się szuka odpowiedzi nie tylko na pytanie, czym jest wartość, lecz także na pytania o to, co jest wartościowe, jak istnieją wartości, jak się je rozpoznaje oraz jak funkcjonują w rozwoju osoby i w kulturze. Szkoła odgrywa więc szczególną rolę w kształtowaniu się człowieka, a tym samym - w kształtowaniu się kultury.
\end{abstract}

Słowa kluczowe: szkoła, kultura szkoły, szkoła katolicka, system prewencyjny, urzeczywistnianie wartości.

Szkoła jako instytucja społeczna zmienia się wraz z kontekstem jej funkcjonowania. Rdzeń zmiany (kierunek) można określić jako poszukiwanie modelu szkoły, sprzyjającego rozwojowi zarówno jednostki, jak i społeczeństwa (uwzględniającego interesy społeczeństwa i jednostki). Odmienne poglądy na to, czym jest szkoła, jaką rolę pełni w społeczeństwie, jakim wartościom służy, prowadzą do innej filozofii konstruowania programów szkolnych, opierających się na różnych teoriach rozwoju człowieka i sięgających w związku z tym do zróżnicowanych teorii edukacyjnego działania (Gołębniak 2003, s. 117-122). Józef Kuźma proponuje nazwać naukę o teoretycznych i praktycznych zagadnieniach działalności szkoły „scholiologią" (z greckiego: schole - szkoła i logos - nauka). Jej przedmiotem byłyby badania działalności szkoły jako instytucji społecznej, jej systemu organizacyjnego, funkcji 
i programów dydaktycznych, wychowawczych i kulturalnych w trzech wymiarach czasowych: przeszłości, teraźniejszości i przyszłości. Szkoła zatem - jak stwierdza J. Kuźma - stanowi złożone środowisko społeczne i edukacyjne, w którym spotykają się trzy przestrzenie edukacyjne: szkolna, pozaszkolna i wirtualna. Każda z tych przestrzeni oddziałuje na inne receptory dziecka za pomocą bodźców werbalnych, wizualnych i audytywnych, cyfrowych oraz interaktywnych. Dla zapewnienia harmonijnego, wielostronnego rozwoju ucznia te trzy przestrzenie edukacyjne powinny się wzajemnie uzupełniać i współdziałać, a nie rywalizować ze sobą czy się wykluczać. Innych treści i wartości dostarczają spotkania z nauczycielem w szkole, innych zaś wycieczki czy surfowanie w Internecie. Kompetentny nauczyciel powinien umieć i chcieć wykorzystać te nowe potencjalne możliwości, jakie płyną z różnych przestrzeni edukacyjnych (Kuźma 2013, s. 17, 48-49). W tak nakreślonym temacie skoncentruję się na trzech kwestiach. Najpierw się zastanowię, jaki kształt powinna przyjąć szkoła, w tym także szkoła katolicka, budująca własną kulturę organizacyjną. Następnie wyjaśnię tożsamość i specyfikę szkoły salezjańskiej. Ostatnim etapem będzie prezentacja urzeczywistniania wartości w kulturze organizacyjnej szkoły salezjańskiej.

\section{Kultura organizacyjna szkoły}

Termin „kultura” jest pojęciem wieloznacznym. Jeśli pierwotnie kultura oznaczała uprawę roli, to później wszystko to, co podległe „uprawie” prowadzonej przez człowieka, zostawało naznaczone wyrażeniem "kultura”. Stąd pojawiła się „kultura duchowa” i „kultura materialna”, „kultura przyrodzona” i „kultura nadprzyrodzona”, „kultura jednostki” i „kultura społeczeństw”, „czynności kulturowe” i „wytwory kulturowe”, „kultura zastana” i „kultura tworzona”, „kultura ludowa” i „kultura naukowa”, „kultura wiejska” i kultura miejska”, „kultura religijna” i „kultura laicka”, „kultura fizyczna” i „kultura duchowa”, wreszcie „człowiek kulturalny” i „człowiek niekulturalny”. Momentem decydującym dla zrozumienia samej kultury w jej najbardziej podstawowym rozumieniu jest pierwotny akt poznania, który zawsze jakoś trwa w tym wszystkim, gdzie są momenty poznawcze. Każdy bowiem ludzki czyn charakteryzuje się świadomością (akty poznania) i dobrowolnością (akty woli kierowanej rozumem) (Krąpiec 1999, s. 106-112). W sensie metaforycznym kultura przeciwstawiana naturze oznacza pielęgnowanie i uszlachetnianie cielesno-duchowych predyspozycji człowieka. W sensie szerokim (analogicznym, typologicznym i aksjologicznym) kulturą nazywa się całość ludzkich zachowań i działań oraz ich wytworów. Nie istnieje żadna dostatecznie ogólna i powszechnie przyjęta definicja kultury. Formalnie wyróżnia się dwa sposoby rozumienia kultury: sposób dynamiczny - określany jako działanie, szczególny sposób ludzkiego zachowania i przetwarzającego świat działania oraz sposób statyczny, czyli dzieło, wynik materialnej i duchowej działalności człowieka w postaci całokształtu materialnych i duchowych dóbr oraz 
zdobyczy kulturowych. Faktem bezspornym jest jednak to, że kultura ma w życiu człowieka charakter zasadniczy i uniwersalny. Człowiek tworzy kulturę, ale i ona kształtuje jego życie (Bronk 1997, s. 332-333).

„Pozostając w ścisłym związku z ludźmi i z ich historią, kultury podlegają takiej samej dynamice, jaka występuje w dziejach człowieka. Tak więc można w nich dostrzec przekształcenia i procesy rozwojowe dokonujące się w wyniku kontaktów między ludźmi, którzy przekazują sobie nawzajem różne modele życia. [...] Każdy człowiek jest włączony w jakąś kulturę, zależy od niej i na nią oddziałuje. Człowiek jest jednocześnie dzieckiem i ojcem kultury, w której żyje. We wszystkie przejawy swego życia wnosi coś, co odróżnia go od reszty stworzenia: nieustanne otwarcie na tajemnicę i nieugaszone pragnienie wiedzy. W konsekwencji każda kultura kryje w sobie i wyraża dążenie do jakiejś pełni” (Jan Paweł II 1998, nr 71). Człowiek tworzy kulturę, poprzez którą rozwija się i doskonali i jest przez nią kształtowany. Z jednej strony materialne dzieła kultury świadczą zawsze o jakimś „uduchowieniu" materii, o poddawaniu tworzywa materialnego energiom ludzkiego ducha, inteligencji, woli, z drugiej zaś strony, duchowe dzieła kultury świadczą o swoistej „materializacji” ducha i tego, co duchowe. A zatem w kulturze trzeba szukać zawsze całego integralnego człowieka w całej prawdzie jego duchowo-cielesnej podmiotowości. „Kultura otwiera perspektywę ludzkiego rozwoju ze względu na prawdę (wiedza), dobro (moralność), piękno (twórczość), boskość (religia). Cywilizacja umożliwia edukację w ramach społeczności zorganizowanej, szerszej niż rodzina i dłużej niż aktualnie żyjące pokolenie. [...]. Symbolem miejsca edukacji w kulturze jest szkoła. Już nie tylko rodzice, nie tylko dom, ale całkiem odrębna instytucja, niemająca odpowiednika w świecie zwierząt, przystosowana jest do edukacji” (Jaroszyński 2005, s. 13-14).

Każda organizacja wykształca swoją własną kulturę. Kultura łącząca ludzi w organizacji pozostaje w bardzo ścisłym związku z efektywnością organizacji. Początki zastosowań pojęcia kultury w badaniach edukacyjnej skuteczności szkoły datuje się na przełom lat 8o. i 9o. ubiegłego wieku. Podobnie jak w wypadku kultury firmy lub korporacji, zakłada się, że kultura szkoły ma związek z jej skutecznością w zakresie osiągnięć szkolnych uczniów, przebiegu kształcenia, postaw wobec zdobywania wiedzy i innych wymiarów funkcjonowania psychospołecznego uczniów, takich jak zdrowie psychiczne lub zachowania problemowe (Kostera 1994, s. 14-16; Ostaszewski 2014, s. 14). Kulturową tożsamość szkoły można określić jako zbiór podzielanych przez personel szkoły i jej uczniów częściowo świadomie, a częściowo nieświadomie wartości, norm, symboli i przekonań, które w znaczącym stopniu wyznaczają zachowania kręgów związanych ze szkołą, a także wzmacniają poczucie odrębności i wspólnoty. Na kulturową tożsamość szkoły składa się zwykle kilka podstawowych elementów. Jest to zjawisko wielowarstwowe, a wartości, normy, przekonania i symbole, które leżą u podstaw zachowań kręgów związanych ze 
szkołą, nie zawsze pokrywają się z wartościami i normami deklarowanymi w oficjalnych dokumentach i deklaracjach szkoły (Szczupaczyński 2004, s. 43-44)1.

Kultura organizacyjna oferuje wspólny system znaczeń i jednocześnie odróżnia jedną organizację od drugiej. Spełnia ona dwie podstawowe funkcje: informuje osoby spoza przedsiębiorstwa o tym, kim są pracownicy i co reprezentują oraz jest swoistym kodeksem wzorów zachowań i wzajemnych relacji (Buhler 2002, s. 235-242). Mówiąc o szkole jako organizacji, można wyróżnić:

- wytwory materialne i symboliczne. Zalicza się tu architekturę budynku szkoły, strukturę organizacyjną, utrwalone wzory zachowań, historie z życia szkoły, symbolikę i rytuały;

- pożądane wartości, normy, standardy i cele. Wyrażają one to, czego szkoła oczekuje od swoich uczniów i nauczycieli;

- podstawowe przekonania, sposoby myślenia, przyjęte ideologie. Mają one istotny wpływ na organizację struktury szkoły i na jej aksjologię (Ostaszewski 2014, s. 16). „Kultura szkoły to wspólne przekonania i wartości, które są «spoiwem» tworzącym ze szkoły jeden organizm. Wynikają one z określonego systemu społecznego i prawnego, wewnętrznej struktury szkoły, działań dyrektora i nauczycieli. $\mathrm{Na}$ kulturę szkoły składają się:

- struktura szkoły, cechy socjodemograficzne uczniów i nauczycieli;

- architektura, wyposażenie, oferta pozalekcyjna;

- przekonania, wartości;

- wzory zachowań;

- sposoby rozwiązywania problemów podzielane przez członków społeczności szkolnej" (Okulicz-Kozaryn 2015).

Najbardziej rozpowszechnionym sposobem myślenia o kulturze organizacyjnej szkoły jest model kliniczny Edgara Scheina. W modelu tym kultura składa się z kilku poziomów wyodrębnionych ze względu na trwałość i widoczność. Pierwszy poziom stanowią artefakty (językowe, behawioralne i fizyczne), drugi - normy i wartości, trzeci, będący podłożem kultury - to założenia. E. Schein podzielił założenia kultury organizacyjnej szkoły na pięć umownych grup:

1) założenia w sprawie związku szkoły z otoczeniem - dają odpowiedź na pytanie o obraz szkoły i jej misję, jakie ma ona kontakty ze światem zewnętrznym, jak strzeże swoich granic, dla kogo je otwiera i czy jest uzależniona od otoczenia;

1 W literaturze funkcjonuje kilka ogólnych definicji kultury szkoły, a mianowicie:

a) kultura szkoły składa się z wspólnie podzielanych przekonań i wartości, które spajają społeczność szkolną w jeden organizm;

b) kultura szkoły jest rodzajem obiektywu, przez który członkowie społeczności szkolnej widzą siebie i świat dookoła;

c) kultura szkoły składa się z niepisanych zasad i tradycji, norm i oczekiwań, które nadają ramy wszystkiemu - jak ludzie się zachowują, ubierają, o czym rozmawiają, czy szukają pomocy u kolegów, czy tego nie robią, jak nauczyciele traktują swoją pracę i uczniów (Ostaszewski 2014, s. 15). 
2) założenia o naturze ludzkich działań przybliżają wizję człowieka (np. w co chce wyposażyć ucznia szkoła) obowiązującą w szkole;

3) założenia w sprawie prawdy i czasu - czy prawda ma w szkole charakter obiektywny, czy subiektywny oraz czy sposób podejścia do czasu koncentruje się na przeszłości, teraźniejszości, a może przyszłości;

4) założenia o naturze ludzkiej - zestaw przekonań o uczniu: jaki on jest, w jaki sposób można go kształtować;

5) założenia o związkach między ludźmi - ukazuje hierarchię władzy, pozycje poszczególnych osób w społeczności szkoły oraz więzi społeczne, które w niej istnieją (Adrjan 2011, s. 15).

O tym, czy tożsamość kulturowa szkoły jest słaba, czy też silna, decyduje pięć kryteriów: wyrazistość elementów składających się na tę tożsamość, stopień ich upowszechnienia, głębokość zakorzenienia, zakres obowiązywania i sposób podtrzymania. Silna tożsamość kulturowa szkoły:

- po pierwsze, ukierunkowuje i pobudza działania jej uczestników, integruje pracowników wokół celów organizacji i środków przyjętych dla ich realizacji;

- po drugie, zapewnia osobom z nią związanym poczucie przynależności i misji, przez co ich praca nabiera sensu i szerszego znaczenia;

- po trzecie, polepsza funkcjonowanie organizacji także poprzez usprawnienie komunikacji. Ponieważ pracownicy podzielają określone wartości i wytworzony w organizacji kulturowy kod porozumiewania się, szybciej dochodzą do porozumienia i podejmują kolegialne decyzje.

Siła kultury odnosi się więc do zależności między jasnym wyrażeniem norm i wartości a stopniem (rygorystycznością) wprowadzenia ich w życie. Silne kultury definiują i egzekwują pożądane zachowania, słabe natomiast określają, jak ludzie mogą, a więc nie muszą się zachowywać (Szczupaczyński 2004, s. 43-44; Drewnowska, Tłuściak-Deliowska 2015, s. 47-49). Kultura organizacji w dużym stopniu definiuje zachowania jej członków, stanowi klucz do ich interpretacji. Poznanie kultury umożliwia zatem lepszy wgląd w rozumienie ludzkich zachowań. Silna tożsamość kulturowa szkoły zapewnia osobom z nią związanym poczucie przynależności i misji, buduje poczucie wspólnotowości, zwiększa poczucie lojalności wobec szkoły i identyfikacji z nią.

Szkoła katolicka jest strukturą społeczną, mającą swoje charakterystyczne cele i metody działania, które jednak nie odbiegają w sposób zasadniczy od celów i metod działania każdej innej szkoły. W świetle nauki Soboru Watykańskiego II, wyrażonej w Deklaracji o wychowaniu chrześcijańskim „Gravissimum educationis”, szkoła katolicka „nie mniej niż inne szkoły zdąża ona do celów kulturalnych i do prawdziwie ludzkiej formacji młodzieży. Właściwością zaś jej jest to, że stwarza w społeczności szkolnej atmosferę przesiąkniętą ewangelicznym duchem wolności i miłości, dopomaga młodzieży, aby w rozwijaniu własnej osobowości wzrastała zarazem wedle nowego stworzenia, którym stała się przez chrzest, a całą ludzką kulturę porządkuje ostatecznie zgodnie $\mathrm{z}$ orędziem zbawienia, tak aby poznanie, 
które wychowankowie stopniowo zdobywają odnośnie do świata, życia i człowieka, było oświetlone wiarą” (GE 8)². W tym też kontekście „nie da się traktować szkoły jako instytucji odrębnej od innych placówek wychowawczych i zarządzanej osobno, musi ona być powiązana ze światem polityki, ekonomii, kultury i ze społeczeństwem jako całością. [...] W ten sposób jasna staje się publiczna rola szkoły katolickiej, nie inicjatywy prywatnej, ale wyrazicielki rzeczywistości eklezjalnej, z istoty swej mającej charakter publiczny. Pełni ona funkcję społecznie użyteczną i choć zostało jasno powiedziane, że kształt nadaje jej wiara katolicka, to jednak nie jest zarezerwowana jedynie dla katolików, lecz otwiera się dla wszystkich, którzy zaakceptują i podejmą przyjętą ofertę programową. Ten wymiar otwartości jawi się szczególnie wyraźnie w krajach, w których większość stanowią niechrześcijanie i rozwijających się, gdzie od zawsze szkoły katolickie, bez żadnej dyskryminacji, wniosły postęp cywilizacyjny i awans osoby ludzkiej. Ponadto obecność szkolnictwa katolickiego obok szkół państwowych gwarantuje pluralizm w kulturze i wychowaniu, a zwłaszcza wolność i prawo rodzin do realizowania takiego kierunku wychowawczego, jaki pragną one dać swoim dzieciom” (Szkoła katolicka u progu trzeciego tysiaclecia 2016, n. 16) ${ }^{3}$.

Szkoła katolicka ma niejako podwójny cel i wymiar działania, odpowiednio do przyjętego w nauczaniu Kościoła prawa wszystkich ludzi do wychowania. Ma zapewnić formację ludzką i chrześcijańską. W tym też kontekście można określić zasadnicze cele szkoły katolickiej, którymi są:

1) uświadomienie wychowankom ich osobowej godności, jako obrazu Boga, i osobowej struktury; motywowanie ich do rozwijania własnego człowieczeństwa, rozumianego w sposób osobowy poprzez wspomaganie rozwoju fizycznego, intelektualnego, moralnego, społecznego, kulturalnego, estetycznego oraz poprzez rozwój duchowy - jako świadomą orientację na wartości duchowe, głownie prawdę, dobro, piękno, a w ujęciu chrześcijańskim - na zwieńczającą je świętość;

2) kształcenie postaw szacunku, miłości, gotowości do pomocy i ofiarnej służby drugiemu i innym we wspólnocie, przede wszystkim we wspólnotach naturalnych - w rodzinie, narodzie, we wspólnotach życiowych - państwowej, kulturowej, ludzkiej, oraz we wspólnotach z wyboru: religijnych, zawodowych, sytuacyjnych;

2 „Szkołę wtedy uważa się za katolicką, gdy jest kierowana przez kompetentną władzę kościelną albo kościelną osobę prawną publiczną, albo za katolicką została uznana przez władzę kościelną dokumentem na piśmie. (...) Żadna szkoła, chociażby rzeczywiście była katolicka, nie może nosić nazwy szkoła katolicka bez zgody kompetentnej władzy kościelnej" (Kodeks prawa kanonicznego 1984, kan. 803, \$1 i $\$ 3)$.

3 „Poprawne stosunki pomiędzy państwem a szkołą, nie tylko katolicką, polegają nie tyle na rozwiązaniach instytucjonalnych, co na przestrzeganiu prawa człowieka do uzyskania odpowiedniego wykształcenia, zgodnie z wolnym wyborem". Tamże, n. 17. 
3) kształcenie tożsamości kulturowej oraz odpowiedzialności za kulturę i aktywnej obrony wartości z nią związanych;

4) stwarzanie poprzez odpowiedni poziom, wymagania i zachętę warunków wewnętrznych i zewnętrznych sprzyjających rozwojowi osobowemu i religijnemu;

5) przygotowanie do kompetentnego i krytycznego korzystania z osiągnięć cywilizacyjnych, traktowania ich jako środek do rozwoju osobowego;

6) formowanie religijne uczniów wierzących-katolików oraz zapoznawanie $\mathrm{z}$ religią katolicką uczniów innych wyznań i niewierzących, a także przygotowanie wychowanków do odpowiedzialnego udziału w życiu Kościoła.

Działalność szkoły wynika z ujmowania siebie, innych, świata w świetle wiary katolickiej. Ideałem w szkole katolickiej jest więc człowiek osobowo dojrzały, a dla osób ochrzczonych - świadomy swej wiary chrześcijanin. Ponadto cele powyższe stanowią podstawowy wymiar aksjologii szkoły katolickiej. Ważne jest zatem kultywowanie tradycji szkoły, wyjaśnianie i pielęgnowanie obrzędowości, przyjęcie symboli związanych ze szczególnie cenionymi wartościami, takimi jak: patron szkoły, sztandar, pamiątki (Olbrycht 2006, s. 94-97).

W dziejach Kościoła szkoła katolicka znana jest przede wszystkim z działalności zakonów. Myśl profetyczna założyciela Zgromadzenia jest charyzmatem, który sprawia, że szkoła jest „katolicką”, ale jednocześnie jednym z rodzajów szkół katolickich. Uznanie istnienia wielości powołań w Kościele nadaje nowe znaczenie obecności osób z różnych zgromadzeń zakonnych (osób konsekrowanych) w obszarze wychowania szkolnego. Historia Kościoła bogata jest we wspaniałe przykłady osób konsekrowanych, które wyrażały i nadal wyrażają swoje dążenie do świętości przez pracę pedagogiczną, ukazując zarazem świętość jako cel wychowania (Kongregacja Wychowania Katolickiego 2003, n. 15-21). Dokumenty Towarzystwa Salezjańskiego podkreślają, że szkoła salezjańska powstała w Oratorium na Valdocco (Turyn), aby odpowiedzieć na konkretne potrzeby młodzieży i włączyć się w powszechny program wychowania i ewangelizacji młodzieży, szczególnie najuboższej. Szkoła zatem jest miejscem, w którym urzeczywistnia się kulturę, uczy krytycznego spojrzenia na otaczający świat, udziela usystematyzowanej odpowiedzi na potrzeby wieku dorastania, przekazuje koncepcję świata, człowieka i historii. Tożsamość i specyfikę szkoły salezjańskiej określa się poprzez wyjaśnienie podstawowych pojęć - szkoła, katolickość, salezjańskość (Salezjańskie duszpasterstwo młodzieżowe. Podstawowe punkty i odniesienia 1999, s. 68-71). Ksiądz Bosko, budując system prewencyjny na podstawie doświadczeń swego życia, wiedział, że należy stworzyć system wychowania integralnego, poprzez który młody człowiek otrzyma pomoc w rozwoju naturalnym, kulturowym i duchowym. W pracy pedagogicznej oznaczało to zainteresowanie się wychowankiem, staranie o to, aby nawiązać z nim dialog, zrozumienie jego uczuć, dostrzeżenie jego prawdziwego życia. Punktem wyjścia dla księdza Bosko było konkretne, „to”, a nie inne dziecko wraz ze swymi potrzebami, radościami i nadziejami. Podkreślał, że prawdziwy i trwały rozwój każdego człowieka ma 
źródło w jego własnym sercu, życiu i wolności. Oddziaływanie wychowawcze trzeba widzieć zatem jako szczególną sytuację międzyosobową, rozumianą jako „obecność" osoby oddanej całkowicie dla dobra drugiego. W wychowaniu według księdza Bosko chodziłoby więc o rzeczywiste spotkanie z młodym człowiekiem, przyjęcie i zaakceptowanie go, tworzenie środowiska bogatego $w$ wartości ludzkie i personalną relację wychowawczą. W liście z 1883 roku na temat systemu prewencyjnego ks. Bosko pisał tak: „W pierwszym rzędzie, jeśli chcecie okazać, że naprawdę pragniecie dobra waszych uczniów i skłonić ich do wypełniania obowiązków, musicie zawsze pamiętać, że jesteście rodzicami tej kochanej młodzieży, która cały czas jest ukochanym przedmiotem moich trosk, nauki, misji kapłańskiej i pracy naszego Zgromadzenia. Jeśli zaś macie być prawdziwymi ojcami waszych uczniów, musicie mieć także ojcowskie serce" (Bosko 1990, s. 260).

\section{Urzeczywistnianie wartości w kulturze organizacyjnej szkoły salezjańskiej}

Każda szkoła jest elementem szerszej kultury społeczeństwa i narodu, wprowadza w kulturę i ją buduje, pomaga w niej konstruktywnie uczestniczyć i twórczo się rozwijać. Jako społeczność ma swoją wewnętrzną kulturę - swoją historię, tradycję, obrzędowość, symbolikę, swoje wartości, wzory, normy zarówno formalnie deklarowane i zapisane, jak i nieformalnie funkcjonujące, typowe zachowania członków społeczności szkolnej, język i sposoby porozumiewania się, sposoby rozwiązywania problemów, styl działania i atmosferę. Kultura ta oddziałuje na samo środowisko danej szkoły, ale i szerzej, na zewnątrz, przez naturalne interakcje społeczne i programowe działania na rzecz innych. Szkoła odgrywa więc szczególną rolę w kształtowaniu się człowieka, a tym samym - w kształtowaniu się kultury (Olbrycht 2014, s. 25-26). Treści, które są przekazywane w procesie wychowania, powinny wprowadzać wychowanka w całość dorobku ludzkiej kultury, z zachowaniem i ukazaniem hierarchii dóbr kulturalnych. W tym sensie „jedynie żywa kultura - dochowująca wierności swym źródłom, a równocześnie objawiająca swą siłę twórczą w płaszczyźnie artystycznej, literackiej, filozoficznej i duchowej - może wytrzymać zderzenie z innymi kulturami. [...] Po to, żeby być pełnowartościowym uczestnikiem tej wielkiej dysputy, jaką prowadzą kultury, musimy powrócić do własnych źródeł greckich, hebrajskich i chrześcijańskich. By stanąć w obliczu kogoś odmiennego od siebie, trzeba być sobą" (Ricoeur 1991, s. 176).

Realizacja wartości odbywa się zawsze w odniesieniu do konkretnej sytuacji. „Obok wpływu wychowawczego rodziny - stwierdza Jan Paweł II - trzeba podkreślić działalność szkoły, otwierającej horyzonty bardziej rozległe i uniwersalne. Według koncepcji księdza Bosko szkoła, oprócz przyczyniania się do rozwoju kulturalnego, społecznego i zawodowego młodzieży, powinna jej dostarczyć odpowiedniego zasobu wartości i zasad moralnych. W przeciwnym razie byłoby niemożliwe konsekwentne, pozytywne i uczciwe życie i działanie w społeczeństwie pełnym napięć i konfliktów" (Jan Paweł II 2015, s. 75). Zatem inaczej się szuka 
odpowiedzi nie tylko na pytanie, czym jest wartość, lecz także na pytania o to, co jest wartościowe, jak istnieją wartości, jak się je rozpoznaje oraz jak funkcjonują w rozwoju osoby i w kulturze. Jeśli jednak mówimy o urzeczywistnianiu wartości, przesądzamy z góry, że w jakiś sposób one istnieją, co więcej, że „wchodzą" niejako w rzeczywistość, w której mogłoby ich nie być. Jeśli mówienie o urzeczywistnianiu czegoś ma sens, to trzeba się zgodzić, iż się wie co ma być urzeczywistniane. To coś może być z razu jedynie projektem, czymś pomyślanym jedynie, musi jednak w jakiś sposób istnieć - choćby w naszej myśli. Praca ta wymaga widzenia wartości, której odpowiednik pragniemy urzeczywistnić, polega zaś na takim przetwarzaniu istniejącego stanu rzeczy, aby owo urzeczywistnienie mogło się dokonać. Wartości „same w sobie” są bezsilne, niezrealizowane, są - z punktu widzenia rzeczywistości - niczym. Gdy jednak „staną się ciałem”, okazuje się, że to one właśnie są, zgodnie ze swą istotą, czymś najważniejszym. Co więcej: to one nadają sens istnieniu, a przez to stają się jego racją (Kamiński 1989, s. 293-294; Stróżewski 1992, s. 57-67). Wartości nie są poszukiwane i „nazwane” dla siebie samych - mają wskazywać horyzonty i drogi realizacji nowych projektów. W tym też kontekście można wskazać na następujące treści kultury szkoły salezjańskiej w urzeczywistnianiu wartości:

1) określona wizja antropologiczna - określenie podstawy antropologicznej propozycji formacyjnej szkoły jest coraz pilniejszą potrzebą w dzisiejszych społeczeństwach. Z istoty osoby ludzkiej wynika to, że chce zawsze być pełniej sobą, formować się, doskonalić. Nigdy nie może powiedzieć o sobie, że jest w pełni „zaktualizowana”, ale świadoma tego, że ciągle jest w drodze. Osoba ludzka doświadcza swego człowieczeństwa w takiej mierze, w jakiej jest zdolna uczestniczyć w człowieczeństwie drugiego. Istnienie $\mathrm{z}$ drugim obejmuje zarówno poziom bytu osoby ludzkiej - mężczyzna/kobieta - jak i poziom etyczny działania. Podstawą ludzkiego etosu jest stworzenie człowieka na obraz i podobieństwo Boga. W tym też kontekście „system zapobiegawczy, już z samej nazwy, wymaga troskliwego zajęcia się poszczególnymi «osobowościami» wychowanków, w których każdy znajduje się w centrum procesu wychowawczego, polegającego na zachęcaniu, dawaniu propozycji, otwieraniu możliwości, dokonywaniu wyborów i podejmowaniu decyzji" (Cian 2001, s. 24). Każdy uczeń powinien być traktowany indywidualnie, z uwzględnieniem środowiska rodzinnego, osobistej historii, przymiotów i zainteresowań. Wynika z tego znaczenie ponownego potwierdzenia humanistycznego i duchowego wymiaru wiedzy i różnych dyscyplin szkolnych. $\mathrm{Za}$ pośrednictwem studium i podejmowanych badań osoba przyczynia się do doskonalenia siebie i swojego człowieczeństwa. $\mathrm{W}$ tej perspektywie wiedza może pomóc w znalezieniu motywacji do życia, w otwarciu się na poszukiwanie Boga, może być doświadczeniem wolności opartej na prawdzie, służącej dojrzewaniu i promowaniu człowieczeństwa, jednostki i całej wspólnoty (Cian 2001, s. 24). 
2) misja wychowawcza: „wychować uczciwych obywateli i dobrych chrześcijan" - msja organizacji określa podstawowe cele, wartości i zasady działania, wyrażone w specyficzny sposób, które orientują codzienną aktywność członków organizacji, bez względu na treść realizowanych przez nich zadań i okoliczności, w jakich się ona odbywa. Misja organizacji odpowiada na pytanie, po co organizacja istnieje, jak działa i do czego dąży. Zawiera więc wskazanie ogólnych celów i sposobów działania w konkretnym środowisku społecznym (Szczupaczyński 2004, s. 52-53). Poświęcając się misji wychowawczej w szkole, osoby konsekrowane angażują się w promocję godności osoby ludzkiej, współpracując, aby szkoła stała się miejscem wychowania integralnego, ewangelizacji i uczenia się żywego dialogu między osobami należącymi do różnych kultur, religii i środowisk społecznych. Oznacza to, że szkoła salezjańska nie promuje aktywizmu ideologicznego, połączonego ze szczególnymi partyjnymi wyborami politycznymi, ale formuje do wrażliwości społecznej i politycznej, która ma prowadzić do zaangażowania własnego życia, rozumianego jako misja dla dobra wspólnoty społecznej, ze stałym odniesieniem do niezbywalnych wartości ludzkich i chrześcijańskich. Jan Bosko uczył wychowywać obywateli odpowiedzialnych, poprzez dojrzewanie konkretnych doświadczeń wiary, które winny się wyrażać w działaniu praktycznym, odpowiednim do rodzących się stale nowych potrzeb. Współczesny wychowawca musi zatem umieć uważnie odczytywać znaki czasu, by móc dostrzec pojawiające się wartości, które pociągają młodzież, takie jak: pokój, wolność, sprawiedliwość, promocja kobiety, solidarność, postęp, ochrona środowiska (Chavez 2013, s. 13-17). „Ksiądz Bosko uczy nas przede wszystkim, aby nie stać bezczynnie, ale się zaangażować, aby zaproponować ludziom młodym integralne doświadczenie wychowawcze [podkr. S. Ch.], które mocno oparte na wymiarze religijnym, zaangażuje umysł, uczucia, całą osobę, uważaną zawsze jako stworzoną i kochaną przez Boga. Stąd wywodzi się pedagogika prawdziwie ludzka i chrześcijańska, ożywiana prewencyjną i ogarniającą troską, szczególnie o ludzi młodych z warstw ludowych i marginalizowanych grup społecznych, którym ofiaruje także możliwość wykształcenia i nauczenia zawodu, aby stali się dobrymi chrześcijanami i uczciwymi obywatelami. Działając na rzecz wychowania moralnego, obywatelskiego, kulturowego ludzi młodych, Ksiądz Bosko angażował się dla dobra poszczególnych osób i społeczeństwa obywatelskiego, według planu człowieka, który łączy razem radość - naukę - modlitwę, jak też pracę - religię - cnoty" (Franciszek 2015, S. $283-284)$.

3) wspólnota wychowawcza - współpraca między wieloma podmiotami (uczniowie, rodzice, nauczyciele, personel pomocniczy i administracja). Wspólnota wychowawcza ma możliwość tworzenia środowiska, w którym wartości są przekazywane za pośrednictwem autentycznych relacji między różnymi członkami, którzy do niego przynależą, i innymi instytucjami 
wychowawczymi obecnymi w szkole. Osoby konsekrowane (wspólnota salezjańska) swoją obecnością wnoszą w tym kontekście specyficzny wkład tożsamości i swego powołania. Angażują się w uczynienie szkoły miejscem spotkania, słuchania, wymiany, w którym uczniowie w żywy sposób doświadczają wartości. Pomagają tak ukierunkowywać wybory pedagogiczne, żeby umożliwić przezwyciężenie nadmiernego indywidualizmu, sprzyjać solidarności zamiast rywalizacji, pomocy słabszemu zamiast spychania go na margines, odpowiedzialnemu uczestnictwu zamiast obojętności (Kongregacja Wychowania Katolickiego 2003, n. 46-49). „Na określenie poprawnej relacji pomiędzy wychowawcami a wychowankami ksiądz Bosko lubił używać terminu familiaritá („zażyłość, przyjaźń). Długoletnie doświadczenie przekonało go, że bez tej zażyłości nie można okazać miłości, a bez tego trudno o wzbudzenie zaufania, które jest niezbędnym warunkiem skuteczności w pracy wychowawczej. Ogół celów, które należy osiągnąć, program, wskazania metodologiczne stają się konkretne, jeśli są nacechowane szczerym duchem rodzinnym, tzn., jeśli będą przeżywane w środowisku radosnym, pogodnym i mobilizującym" (Jan Paweł II 2015, s. 84). Ponadto życie wspólnoty wychowawczej powinno stale zmierzać do wychodzenia poza wcześniejsze osiągnięcia oraz do stawiania pytań na poziomie egzystencjalnym. „By być darem z siebie - stwierdza Krystyna Chałas - trzeba «rosnąć» osobowo. Pomnażać swoją kulturę duchową i umiejętnie nią ubogacać drugiego człowieka, ukazując mu jego błędy, ich uwarunkowania, drogę wyjścia, która prowadzi w świat prawdziwych wartości i bratersko go w tej wędrówce wspierać" (Chałas 2006, s. 51).

4) bogactwo charyzmatu wychowawczego. Uznanie istnienia wielości powołań w Kościele nadaje nowe znaczenie obecności osób konsekrowanych w obszarze wychowania szkolnego. Zadanie wychowawcze, zarówno w szkołach katolickich, jak i w innych typach szkół, jest dla osób konsekrowanych powołaniem i wyborem życiowym, drogą świętości. Poprzez szkołę osoby konsekrowane wychowują, pomagają młodemu człowiekowi odkryć własną tożsamość i te autentyczne potrzeby i pragnienia, które zamieszkują w sercu każdego człowieka, a które często pozostają nieznane i niedoceniane, jak głód autentyczności i uczciwości, miłości i wierności, prawdy i harmonii, szczęścia i pełni życia. Szkoła formuje, gdy dostarcza wyraźnej propozycji realizacji tych pragnień, chroniąc je przed deformacją lub tylko częściowym i słabym zaspokojeniem (Kongregacja Wychowania Katolickiego 2003, n. 17-19). „Charyzmat księdza Bosko jest darem Ducha dla całego ludu Bożego. [...] Charyzmat pozwala wnosić, poprzez wychowanie, szczególny wkład w dzieło ewangelizacji młodzieży. Bez wychowania bowiem nie ma trwałej i głębokiej ewangelizacji, nie ma rozwoju i dojrzewania, nie zmienia się mentalność ani kultura. W ludziach młodych jest głębokie pragnienie pełnego życia, prawdziwej miłości, konstruktywnej wolności; często jednak, niestety, zawodzi się ich 
oczekiwania i pozostają one niespełnione. Koniecznie zatem trzeba pomagać młodym w uświadamianiu sobie bogactwa - ich dynamizmu i pozytywnego pragnienia; trzeba ich włączać w projekty, w których uzewnętrznia się bogactwo ludzkie i ewangeliczne; trzeba ich zachęcać, by czynnie włączali się w życie społeczeństwa poprzez pracę, współdziałanie i troskę o wspólne dobro. Od tych, którzy są ich przewodnikami, wymaga to rozszerzenia zakresu działalności wychowawczej z uwzględnieniem nowych form ubóstwa młodzieży, szkolnictwa wyższego, imigracji; wymaga to również poświęcenia szczególnej uwagi rodzinie i jej zaangażowaniu” (Benedykt XVI 2015, s. 206-209).

5) synteza kultury i wiary. „Wychowanie - według księdza Bosko - wymaga szczególnej postawy wychowawcy i całego zespołu sposobów i poczynań, opartych na przekonaniach płynących z rozumu i wiary, które kierują działaniem wychowawczym" (Jan Paweł II 2015, s. 81-82). Spójne, krytyczne i oceniające przekazywanie kultury ma przedstawiać cały szereg wartości i ich przeciwstawieństw, ukazywać hierarchię dóbr kulturalnych. Dążenie do pogodzenia rozumu i wiary, obecne w poszczególnych przedmiotach nauczania, nadaje im jednolitość, specyficzny wyraz i koordynuje, wyłaniając z samej ich istoty szkolny program nauczania chrześcijańskiej wizji świata, kultury i historii. Poszczególne dyscypliny reprezentują nie tylko wiedzę do zdobycia, ale także wartości, które trzeba przyswoić, oraz prawdę do odkrycia. W założeniach wychowawczych katolickiej szkoły nie ma więc miejsca na oddzielenie nauczania od wychowywania, pojęć od mądrości. Wiedza w perspektywie wiary staje się mądrością i nawet pewną koncepcją życia. Wszystko to wymaga klimatu poszukiwania prawdy. Tak więc zarówno dobór treści programowych, jak i sposób ich realizacji powinny obejmować przekaz prawdy i wiedzy oraz ukazywać powiązania między kulturą i wiarą (Szkoła katolicka u progu trzeciego tysiąclecia, n. 14).

6) perspektywa międzykulturowa. Proces globalizacji jest zjawiskiem złożonym w swoim dynamizmie. Ma skutki pozytywne, czyli np. możliwość spotkania między narodami i kulturami, ale ma też aspekty negatywne, które mogą przyczynić się do wytworzenia dalszych nierówności, niesprawiedliwości i spychania słabszych na margines. Szybkość i złożoność zmian wywołanych przez globalizację odzwierciedla się także w szkole, która może być sprowadzona tylko do roli narzędzia przez wymagania struktur produkcyjno-ekonomicznych lub przez przesądy ideologiczne i kalkulacje polityczne, które zaciemniają jej funkcję wychowawczą. „Według koncepcji księdza Bosko szkoła, oprócz przyczyniania się do rozwoju kulturalnego, społecznego i zawodowego młodzieży, powinna jej dostarczyć odpowiedniego zasobu wartości i zasad moralnych. W przeciwnym razie byłoby niemożliwe konsekwentne, pozytywne i uczciwe życie i działanie w społeczeństwie pełnym napięć i konfliktów” (Jan Paweł II 2015, s. 89-90). Dialog między kulturami jawi 
się jako potrzeba wpisana w samą naturę człowieka i kultury. „Poznawanie innych kultur - przy zachowaniu należnego krytycyzmu i solidnych kryteriów etycznych - pozwala lepiej uświadomić sobie wartości i ograniczenia własnej kultury, a zarazem ujawnia istnienie wspólnego dziedzictwa całego rodzaju ludzkiego. Właśnie przez takie poszerzanie horyzontów wychowanie przyczynia się w szczególny sposób do budowy świata bardziej solidarnego i pokojowego. Może też sprzyjać rozkrzewianiu integralnego humanizmu, otwartego na wymiar etyczny i religijny, który potrafi dostrzec, jak istotne znaczenie ma znajomość i poszanowanie kultur i wartości duchowych różnych cywilizacji” (Jan Paweł II 200o, n. 20).

W działaniu urzeczywistniającym wartości człowiek „buduje się” jako wolna, niepowtarzalna osoba. Praca nad spełnieniem siebie jako osoby, praca nad sobą jest pracą całego życia. Pedagog staje przed zadaniem wyposażenia wychowanka w sprawności i struktury, które mogą mu w tej pracy być potrzebne, a także przed zadaniem cierpliwego motywowania go do podejmowania konstruktywnych działań. Zatem „wartości są zarówno tym, w imię czego wychowawca powinien podejmować swoją działalność, jak i tym, co stara się on kształtować w wychowanku. Są one również tym, co - z jednej strony - powoduje ludzkie rozterki i konflikty, z drugiej zaś - umożliwia ich przezwyciężanie i stanowi podstawę umiejętności życia pełnego i twórczego, umiejętności, w której zdobyciu powinien pomóc nauczyciel i wychowawca” (Cichoń 1996, s. 7).

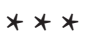

Pedagogicznej refleksji towarzyszy przeświadczenie, że „nie warunki są najważniejsze, ale to, jakim człowiekiem jest nauczyciel, czy ma wizję ucznia, co potrafi rozbudzić w swoich uczniach" (Brzezińska 2015, s. 10). Wychowanie jako działanie i zarazem jako jego doznawanie jest jednością „zapodmiotowioną” w wymiarze tego, co jest specyficznie ludzkie między osobami. Wychowywać znaczy pomagać komuś w odkryciu własnych „możliwości”, „przekazanych” mu jednostkowo w życiu. Wychowanie ma obejmować rozwój całej osoby, tzn. zdolności intelektualnych, emocjonalnych i rozwoju fizycznego, rozwoju wewnętrznego ,ja” i zewnętrznych aspiracji. Kultura szkoły wyrasta na gruncie podejmowania kolejnych wyzwań, zadań, rozwiązywania problemów. „Każda szkoła i każda dziedzina wychowania nieformalnego mogą się stać węzłem olbrzymiej sieci, która - od najmniejszej wsi do najbardziej rozległej metropolii - obejmuje świat nadzieją. W wychowaniu znajduje się bowiem obietnica bardziej ludzkiej przyszłości i bardziej solidarnego społeczeństwa” (Kongregacja Wychowania Katolickiego 2003, n. 84). 


\section{Bibliografia}

Adrjan B. (2011). Kultura szkoły. W poszukiwaniu nieuchwytnego. Kraków: Impuls. Benedykt XVI (2015). Przesłanie z okazji XXVI Kapituły Generalnej Salezjanów. Watykan, 1 marca 2008. W: Chrobak S. (red.), cz. 2: Ksiadz Bosko w wypowiedziach papieży. Warszawa: Wydawnictwo Salezjańskie, s. 206-211.

Bosko J. (1990). List o karach. W: Cian L., Wychowanie w duchu Księdza Bosko, tłum. I. Gutewicz. Warszawa: Wydawnictwo Salezjańskie, s. 259-268.

Bronk A. (1997). Kultura. W: Leksykon filozofii klasycznej. Herbut J. (red.). Lublin: Towarzystwo Naukowe KUL, s. 332-335.

Brzezińska A. (2015). Szkoła, czyli życie tu i teraz. „Psychologia w Szkole”, nr 5 (51), S. 5-12.

Buhler P. (2002). Zarządzanie, tłum. Wiercioch E., Służałek I.. Gliwice: Wydawnictwo Helion.

Chałas K. (2006). Miłosierdzie w podstawowych funkcjach szkoły. „Edukacja. Teologia i Dialog", t. 3, s. 45-51.

Chavez P. (2013). List przełożonego Generalnego «Wzorem Księdza Bosko - wychowawcy ofiarujemy młodzieży Ewangelię radości stosując pedagogię dobroci». „Dokumenty Rady Generalnej”, nr 415, s. 3-30.

Cian L. (2001). System zapobiegawczy św. Jana Bosko i jego charakterystyka, tłum. Gabryel M. Warszawa: Wydawnictwo Salezjańskie.

Cichoń W. (1996). Wartości człowiek wychowanie. Zarys problematyki aksjologiczno-wychowawczej. Kraków: Wydawnictwo Uniwersytetu Jagiellońskiego.

Deklaracja o wychowaniu chrześcijańskim "gravissimum educationis” (1986). W: Sobór Watykański II. Konstytucje, dekrety, deklaracje. Poznań: Pallottinum.

Drewnowska U., Tłuściak-Deliowska A. (2015). Kultura szkoły. Studium teoretyczno-empiryczne. Kraków: Impuls.

Franciszek. (2015). Jak Ksiadz Bosko, z młodzieża i dla młodzieży. W: Chrobak S. (red.). cz. 2: Ksiądz Bosko w wypowiedziach papieży. Warszawa: Wydawnictwo Salezjańskie, s. 283-288.

Gołębniak B. D. (2003). Szkoła wspomagająca rozwój. W: Pedagogika. Podręcznik akademicki. Kwieciński Z., Śliwerski B. (red.). Warszawa: Wydawnictwo Naukowe PWN, s. 98-122.

Jan Paweł II. (200o). Dialog między kulturami droga do cywilizacji miłości i pokoju. Orędzie na Światowy Dzień Pokoju 1 stycznia 2001. Warszawa: Centrum Duszpasterstwa Archidiecezji Warszawskiej.

Jan Paweł II. (1998). Encyklika „Fides et ratio”. Rzym.

Jan Paweł II. (2015). List apostolski „Iuvenum patris” w setna rocznicęśmierci św. Jana Bosko. W: Chrobak S. (red.). cz. 2: Ksiądz Bosko w wypowiedziach papieży. Warszawa: Wydawnictwo Salezjańskie, s. 75-94. 
Jaroszyński P. (2005). Edukacja na rozdrożu cywilizacji. W: Filozofia i edukacja. Jaroszyński P., Tarasiewicz P., Chłodna I. (red.), Lublin: Fundacja „Lubelska Szkoła Filozofii Chrześcijańskiej”, s. 13-21.

Kamiński S. (1989). Jak filozofować? Studia z metodologii filozofii klasycznej. Lublin:

Wydawnictwo Towarzystwa Naukowego KUL.

Kodeks prawa kanonicznego (1984). Poznań: Pallottinum.

Kostera M. (1994). Zarzadzanie personelem. Warszawa: Polskie Wydawnictwo Ekonomiczne.

Krąpiec M. A. (1999). Człowiek w kulturze. Lublin: Redakcja Wydawnictw Katolickiego Uniwersytetu Lubelskiego.

Kuźma J. (2013). Nauka o szkole. Teorie i wizje przyszłej szkoły. „Roczniki Pedagogiczne", t. 5 (41), nr 2, s. 17, 15-52.

Okulicz-Kozaryn K. (2015). Klimat i kultura szkoly a zdrowie psychiczne uczniów i nauczycieli, dostępny na: https://www.ore.edu.pl/index.php?...i-kultura...i... Olbrycht K. (2006). Aksjologia szkoły katolickiej. „Ethos”, nr 75, s. 91-98.

Olbrycht K. (2014). Jana Pawła II myślenie o zwiazkach wiary i kultury - wyzwaniem dla wychowania chrześcijańskiego. „Paedagogia Christiana”, nr 2/34, s. 11-28. Osoby konsekrowane i ich misja w szkole. Refleksje i wskazania (2003). Kongregacja ds. Wychowania Katolickiego. Poznań: Pallottinum.

Ostaszewski K. (2014). Kultura szkoły a zachowania ryzykowne uczniów. „Edukacja”, nr 1 (126), s. 14-24.

Ricoeur P. (1991). Podług nadziei. Odczyty, szkice, studia, (wybrał, opracował i wstępem opatrzył) S. Ciechowicz. Warszawa: Instytut Wydawniczy Pax.

Salezjańskie duszpasterstwo młodzieżowe. Podstawowe punkty i odniesienia (1999).

Kraków: Salezjańskie Centrum Wychowania i Duszpasterstwa.

Stróżewski W. (1992). W kręgu wartości. Kraków: Wydawnictwo Znak.

Szczupaczyński J. (2004). Edukacja a zarządzanie. Pułtusk: Wyższa Szkoła Humanistyczna im. Aleksandra Gieysztora.

Szkoła katolicka u progu trzeciego tysiaclecia (2016). Kongregacja ds. Wychowania Katolickiego, dostępny na: http://www.pedkat.pl/index. php/187-szkola-katolicka-u-progu-trzeciego-tysiaclecia.

\title{
THE CULTURAL IDENTITY OF THE SALESIAN SCHOOL AS THE BASIS OF EDUCATION TOWARDS A VALUABLE LIFE
}

\begin{abstract}
Each organization develops its own culture. This organizational culture largely defines the behaviours of its members; it constitutes the key to their interpretation. Understanding the culture allows better insight into the understanding of human behaviours. Each school is part of the broader culture of the society and the nation, it introduces the culture and builds it, helps to participate constructively in it and develop creatively. As a community has its own internal culture - its history, traditions, rituals, symbols,
\end{abstract}


its values, patterns, and standards both formally declared and written down, as well as informally functioning, typical behaviours of the members of the school community, language and ways of communicating, problem solving, style of action, and atmosphere. This culture influences the environment of a given school, but also more broadly, on the outside, through the natural social interactions and program of action for the benefit of others. Therefore, it looks for answers differently, not only to the question of what value is, but also questions about what is valuable, how values exist, how to recognize them, and how they operate in the development of the individual and culture. The school thus plays a special role in the shaping of the individual, and so - in shaping the culture.

Stanisław Chrobak - doktor habilitowany, profesor nadzwyczajny UKSW. W swoich badaniach podejmuje problematykę z zakresu pedagogiki ogólnej, teoretycznych podstaw wychowania, filozofii wychowania i pedagogiki o inspiracji chrześcijańskiej. Jest członkiem Zespołu Pedagogiki Chrześcijańskiej KNP PAN, Towarzystwa Naukowego Franciszka Salezego oraz Zespołu Teorii Wychowania KNP PAN. Autor m.in. takich książek, jak: Koncepcja wychowania personalistycznego w nauczaniu Karola Wojtyły - Jana Pawła II (Warszawa 1999), Podstawy pedagogiki nadziei. Współczesne konteksty w inspiracji personalistyczno-chrześcijańskiej (2009), Ksiądz Bosko w wypowiedziach papieży, cz. 1 (Warszawa 2014), Ksiadz Bosko w wypowiedziach papieży, cz. 2 (Warszawa 2015) oraz ponad 100 artykułów. Adres korespondencyjny: Wydział Nauk Pedagogicznych UKSW, ul. Wóycickiego 1/3, budynek 15, 01-938 Warszawa. Adres e-mailowy: s.chrobak@uksw.edu.pl. 